The Journal of

\title{
Laryngology and Otology
}

\author{
EDITED BY \\ WALTER HOWARTH \\ ASSISTANT EDITOR \\ G. H. BATEMAN \\ WITH THE COLLABORATION OF \\ V. E NEGUS R, G. MACBETH
}

\section{Contents}

The Management of Cancer of the Laryax (SEMON LectuRE 1953)

F. C. ORMRROD $\checkmark$

"HistamiNe AND itS ANTAgonists"

HENRY DALE $\checkmark$

NASOPHARYNGEAL. FIBROMA AND ITS TREATMENT

J. S. MARTIN $\checkmark$

Cuinicas Records-
HYPEROSTOSIS OF THE TEMPORAL BONE.
B. BLACKLAY
CONGENital Lachrymat. OBstruction
BRIAN REEVES $\checkmark$

GeNERAI NOTES

\section{London \\ Headley Brothers Ltd \\ $1 \circ 9$ Kingsway $\mathrm{WC}_{2}$}




\title{
The Journal of \\ Laryngology and Otology
}

(Founded in 1887 by Morri. MACKknzir and Norris Wolfzenden) EDITED BY

WALTER HOWARTH

\author{
ASSISTANT EDITOR \\ G. H. BATEMAN \\ WTHA THE COLIABOKATION OF \\ $\begin{array}{ll}\text { V. E. NEGUS } & \text { R. G. MACBETH }\end{array}$
}

1. Original Articles are accepted on the condition that they have not been published elsewhere.

2. Manuseripts should be typewritten, on one side only of the paper, and well spaced.

The Harvard system of recording references should be used, e.g. Grens. C., and Brows, D. (1951) 7. Laryng., 65, 33. Abbreviations of Journals should follow the style recommended in World, Medical Periudicals, published by World Health Organisation 1952.

It is most important that authors should verify personally the accuracy of every reference before submitting a paper for publication.

3. Galley proofs and engraver's proofs of illustrations are sent to the author. Corrections, which should be kept to a minimum, must be elearly marked, and no extra matter added.

4. Illustration blocks are provided free up to the limit of $\varnothing_{5}$ per article; beyond this authors are expected to pay half the cost.

5. Orders for reprints should be sent when returning galley proofs, and for this purpose special forms are supplied.

6. Authors of original communications on Oto-Laryngology in other journals are invited to send a copy, or two reprints, to the foumal of Laryngology. If they are willing, at the same time, to submit their own abstract (in English, French, Italian, or German) it will be welcomed.

7. Editorial communications may be addressed to THE EDrror, Jounal of Layygology, c/o HeAdLEY Brothers Lird, IOg Kingsway London $\mathrm{WC}_{2}$.

8. The annual subscription is three guineas sterling (U.S.A. \$10, ) post free, and is payable in advance.

9. Single copies will be on sale at 7s. 6d, each; copies of parts up to Vol. LXIII may be purchased at 4 s. each.

10. All subscriptions, advertising and business communications should be sent to the publishers, HenDLEY Brotrurs LTD, 109 Kingsway London $\mathrm{WC}_{2}$.

United States of America

Orders for this Journal may be sent either through a local bookseller, or to Messrs G. E. Strechert \& Co., 3i-33 East 1oth Street, New York, or they may be sent direct to the publishers, HradLey Brothres LTD, $\log$ Kingsway London W C 2, England.

Plesse mention The Journal of Laryngology when replying to advertisements 


\section{FOR THE EFFECTIVE LOCAL TREATMENT OF SINUSITIS}
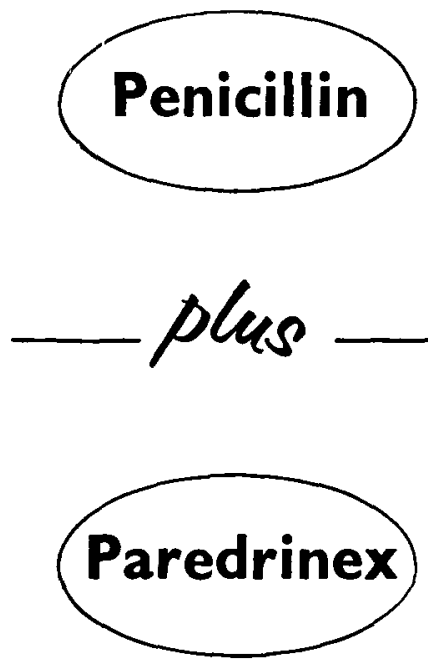

the potent and penetrating antibacterial action of 1,500 units of penicillin per $\mathrm{ml}$. Activity in the presence of pus

rapid, efficient, and safe vasoconstrictor that by shrinking oedematous and engorged tissues enables the penicillin to reach all affected areas in adequate concentration

\section{equals}

\section{PENDEX}

for effective local penicillin therapy

in upper respiratory tract infections,

sinusitis-rhinitis-nasopharyngitis.

Available, on prescription

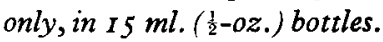
Detailed information on request.

MENLEY \& JAMES, LIMITED, COLDHARBOUR LANE, LONDON, S.E.5 PXP1I 3

for Smith Kline \& French International Co., owner of the trade marks 'Pendex' and 'Paredrinex'

Please mention Tbe Journal of Laryngology when replying to advertisements 


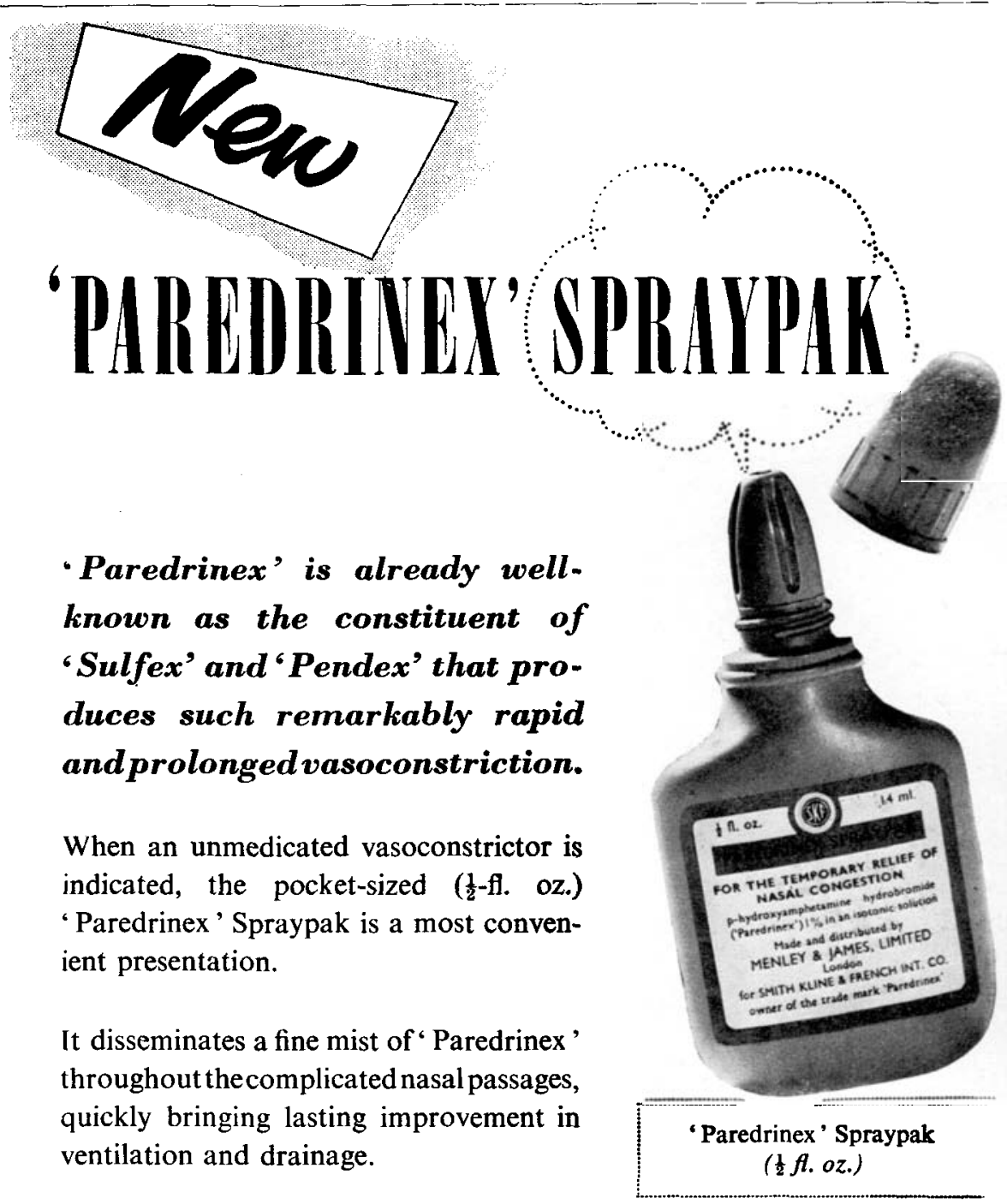

Paredrinex' is already well. inown as the constituent of 'Sulfex' and 'Pendex' that produces such remarkably rapid and prolonged vasoconstriction.

When an unmedicated vasoconstrictor is indicated, the pocket-sized ( $\frac{1}{2}-f$. oz. $)$ 'Paredrinex' Spraypak is a most convenient presentation.

It disseminates a fine mist of ' Paredrinex ' throughout the complicated nasal passages, quickly bringing lasting improvement in ventilation and drainage.

( $\frac{1}{2}$ fl. oz.)

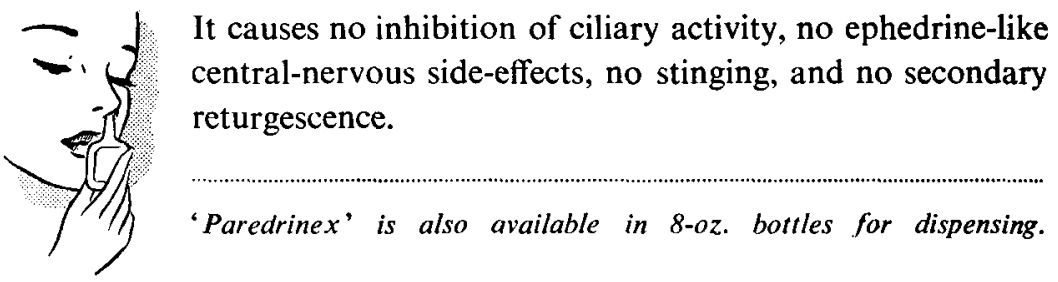

MENLEY JAMES, LIMITED, COLDHARBOUR LANE, LONDON, S.E.5 for Smith Kline \& French International Co., owner of the trade marks 'Paredrinex', 'Spraypak', 'Sulfex' and 'Pendex' PDPI 13

Please mention Tbe Journal of Laryngology when replying to advertisements 


\section{Impacted Wax}

\section{Hemoved swiftly and safely}

Even severely impacted wax can now be safely loosened, softened or dissolved by Cerumol. Pressure syringing is no longer necessary.

Cerumol was clinically tested in a London hospital and is an accepted product for use in a large number of hospitals and general practices throughout the country. It is included in Category No. 4 in the Classified List of Proprietary Preparations issued by the Ministry of Health, and may therefore be prescribed on N.H.S. form E.C.10. Price under the National Health Scheme, 2s. 8d. per 10 c.c. vial with separate dropper. Also packed in $2 \mathrm{oz}$. and $10 \mathrm{oz}$. bottles for hospital use.

Safe, Efficient, Anti-bacterial. Saves Time and Trouble. Obtainable through your Chemist.

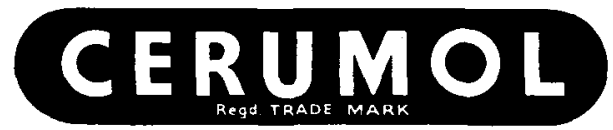

EAR DROPS

\section{A Product of The Lahoratories for Applied Blology Ltd., London, N.16.}

Professional sample and literature available on request from the distributors *

\section{TAMPAX LIMITED,}

Medical Department, 110 Jermyn Street, London, S.W.1.

Telephone : Whitehall 8696. 


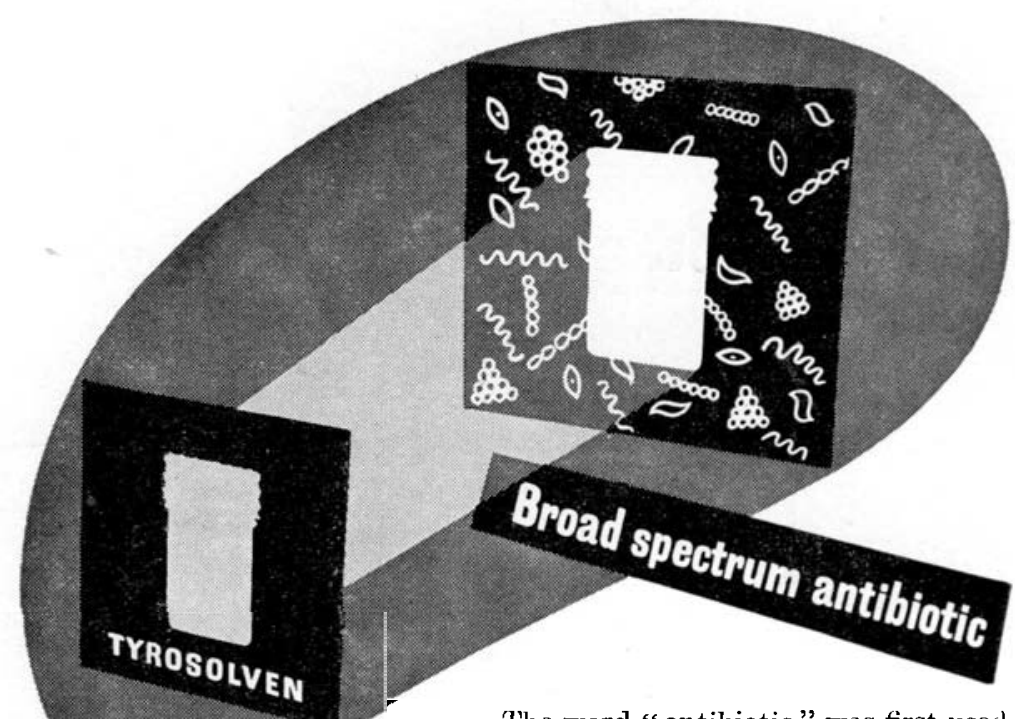

The word "antibiotic" was first used in 1889. Vuillemin, introducing it, said: "The conception is so simple that no one has ever thought of giving it a name". Since then, antibiotics have been produced from fungi, lichens, algae and bacteria. An outstanding member of the bacterial group is tyrothricin, which forms the basis of TYROSOLVEN antibiotic lozenges. It is effective against a wide spectrum ACTIVE of oral bacteria, and relieves superficial CONSTITUENTS: Tyrothricin $1 \mathrm{mg}$., benzocaine $5 \mathrm{mg}$. mouth and throat infections. PACKING:

Tubes of 20 lozenges and dispensing pack. of 250 not subject to Purchase Tax.

\section{Tyrosolven}

No Warner preparation has ever been advertised to the public.

WILLIAM R. WARNER \& Co. Ltd., Power Road, London, W.4. 


\section{ENDOSCOPIC INSTRUMENTS}

as designed for V. F. Negus, M.S., F.R.C.S.

Tracheascope

Bronchoscope, with combined distal and proximal lighting. (9 sizes)

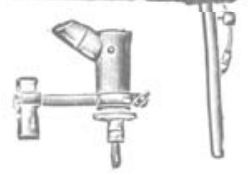

CEsophagoscope with detachable Suction Tube and Proximal Lighting. (s sizes)

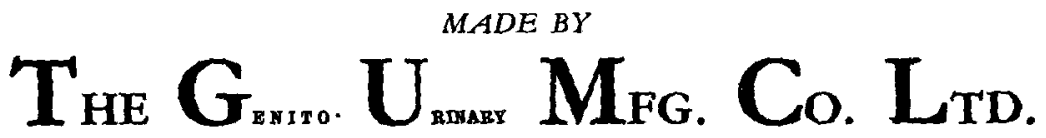
28a, 33 \& 34 DEVONSHIRE STREET, LONDON, W.I

Telephone:

WELBECK 2835 (3 lines)

Telegtams: CYSTOSCOPE, WESDO, LONDON

Please mention The Journal of Laryngology when teplying to advertisements 


\section{THE LARYNGOSCOPE}

A Monthly Journal

devoted to the Diseases of the

EAR, NOSE AND THROAT

Official organ for the American Laryngological, Rhinological and Otological Society

Price $\$ 14.00$ per year

Max A. Goldstein, M.D. FOUNDER
Canada $\$ 13.00$ per year

THEODORE E. WALSh, M.D. EDITOR

\section{SOUTH KINGSHIGHWAY \\ SAINT LOUIS 10, MO.}

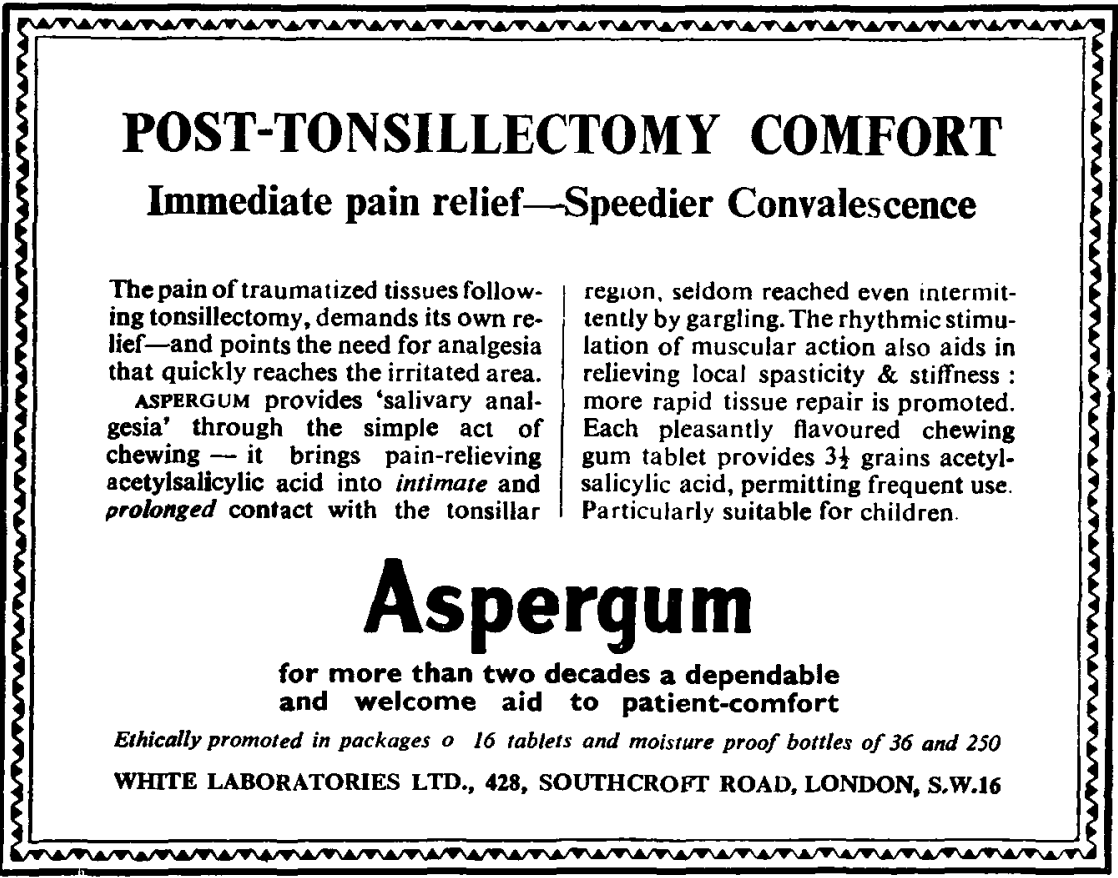

Please mention The Journal of Laryngology when replying to advertisements 


\section{AMPLIVOX MODEL $6 I$ \\ THE CLINICAL AUDIOMETER OF INTERNATIONAL REPUTE}

"Messrs. Amplivox were among the first firms to produce an audiometer in this country, and their larger model is one of the best instruments of the kind now made in the world at a competitive price." - The LANCET, 23-12-50.

- Eleven exact test frequencies 125-12,000 c.p.s.

- Simplified hearing loss dial. The same set of figures is read for both bone and air conduction at all frequencies, and for speech.

- Bone conduction tests can be made from 125-4,000 c.p.s.

- Masking Tone calibrated in decibels, permitting accurate control of masking.

- Double Air receivers enable test tones to be switched instantly from ear to ear.

- Speech test circuit monitors speech level, permitting accurate measurement of hearing loss for speech.

- Loudness Balance Control establishes presence of recruitment in monaural deafness.

- Automatic voltage compensator.

Recruitment Test Set accessory establishes presence of recruitment by amplitude modulation, enabling each ear to be tested independently.

Speech Turntable, English made P.B. and Harvard Spondee Records available.

Full details are available from the manufacturers who will gladly arrange demonstrations if required.

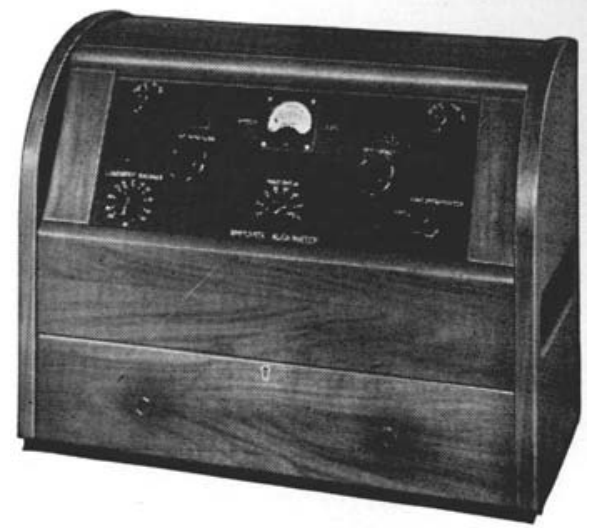

\section{The Basic Instrument of Modern Otology}

\section{ACCURATE • COMPLETE • SIMPLE TO OPERATE}

AMPLIVOX LTD., 2 BENTINCK ST., LONDON, W.I (Welbeck 259I)

Please mention The Journal of Laryngology when replying to advertisements 


\section{CONTENTS}

The Management of Cancer of the Larynx. Semon Lecture 1953. F. C. Ormerod (London) . . . . .

PAGE

"Histamine and its Antagonists." Sir Henry Dale (London) .

Nasopharyngeal Fibroma and its Treatment. J. S. Martin (London)

Clinical Records-

Hyperostosis of the Temporal Bone. B. Blacklay (London)

Congenital Lachrymal Obstruction. Brian Reeves (Salisbury)

\section{BINDING}

\section{Journal of Laryngology \& Otology}

Subscribers wishing to have their Journals bound can do so by sending them to the Publishers.

Volumes are strongly bound in whole dark blue buckram cases, with gold lettering on spine. The cost of binding is $25 \mathrm{~s}$. per volume, including postage.

Some missing parts can be supplied at $7 \mathrm{~s} .6 \mathrm{~d}$. each, or the whole volume, complete in the above binding, for $88 \mathrm{~s}$.

Publishers' cases can be supplied for ros., including postage.

HEADLEY BROTHERS LTD, IO9 KINGSWAY LONDON W C 2

Please mention The Journal of Laryngology when replying to advertisements 